\title{
Evaluation of economic efficiency of the state programme of renovation of residential buildings in Moscow
}

\author{
Svetlana Kolobova ${ }^{1, *}$ \\ ${ }^{1}$ Moscow State University of Civil Engineering, 26, Yaroslavskoye shosse, 129337, Moscow, Russia
}

\begin{abstract}
Renovation of housing estate in Moscow is aimed at prevention of growth of the hazardous dwelling in Moscow, development of the housing estate and their improvement. The programme of renovation is adopted for the period up to 2032 and it will allow eliminating the imbalance of development of the urban environment, which is saved up for the last decades, on the other hand it will prevent mass emergency housing estate in Moscow in the next 10-15 years. Updating of the housing estate is to be based on the development of infrastructure, on the creation of additional conditions for human development, on the ecology, providing complex development of the territory according to the modern requirements to the urban environment. The economic efficiency of renovation of the housing estate will be estimated with the use of indicators of increase in the consumer quality of apartments, blocks of flats, residential districts. The method of calculation of economic effect of renovation before delivery of inhabited and non-residential premises for rent is developed for the definition of payback period and the potential monthly cost of the rent after renovation of buildings. The offered method allows estimating the efficiency of organizational actions of the state programme and it is only a part of assessment of the overall economic efficiency. The offered technique of assessment of economic efficiency of renovation will allow making economically reasonable decisions during various stages of city-planning activity: during preliminary preparation, during planning of the territory, during development and the approval of the design and estimate documentation.
\end{abstract}

\section{Introduction}

The housing issue has always been the central theme of the social-and-economic policy of the whole country, every region, every city, town or urban-type settlement. The issue of housing is the central one for the city of Moscow, as the population of this metropolis is more than 12 million people and there is the largest investment activity of the participants of the investment-and -construction housing market. During the period of mass industrial housing construction (from 1950th to $1970^{\text {th }}$ ) more than 25 million $\mathrm{m}^{2}$ of housing were built in the

* Corresponding author: KolobovaSV@mgsu.ru 
form of five-storey residential buildings. During long maintenance those buildings reached the maximum of physical and moral wear and lost their consumer qualities. Thus, the realistic programme of renovation involves the demolition of emergency and dilapidated houses, the elimination of outdated housing estate, the creation of resettlement fund.

The renovation programme was adopted for the period until 2032. It will eliminate the imbalance of the city environment development, accumulated over the past decade, and also will prevent the mass unfit housing in Moscow in the next 10-15 years.

According to the Resolution the renovation Programme is financed with the attraction of the means of Moscow city budget, as well as other sources (in accordance with the legislation of the Russian Federation). Public-and-private partnership is important. The analysis of the first phase of the renovation proved, that about $70 \%$ of the investment housing contracts yield 1.78 million $\mathrm{m}^{2}$ of housing annually. The period of the implementation of the State programme is 2012-2016. Only 12.7 million $\mathrm{m}^{2}$ of housing was put into operation at the expense of all the sources of financing, including 3.8 million $\mathrm{m}^{2}$ at the expense of Moscow city budget.

An important goal of the State programme "Housing" for the period 2012-2018 is to increase the comfort and safety of living conditions in Moscow, improving the quality of housing estate, the development of the system of housing management in Moscow. To achieve this goal we will need to complete the task of construction of new housing and renovation of the existing residential development, of capital repairs and modernization and of other state obligations for provision of housing for citizens, established by the legislation of the Russian Federation and by the legislation of Moscow. So in 20173.14 million $\mathrm{m}^{2}$ of housing was built at the expense of mixed sources and 0.6 million $\mathrm{m}^{2}$ was built at the expense of the city budget, and in 20183.16 million $\mathrm{m}^{2}$ at the expense of mixed sources and 0.6 million $\mathrm{m}^{2}$ at the expense of the city budget. According to the decree of the government of Moscow "On amending resolution of the Government of Moscow dated 27.09.2011 No. 454" is planned for overhaul and modernization of 4.7 million $\mathrm{m}^{2}$ of housing in 2017 and 2018 . Integral factors were considered for the annual evaluation of economic efficiency of the State programme. One of the main goals, set by the President of the Russian Federation Vladimir Putin at the meeting of the State Council "On the construction industry development and improvement of urban planning", held on the $17^{\text {th }}$ of May, 2016, and the key task of the state Programme of the Russian Federation "Providing affordable and comfortable housing and utilities of citizens of the Russian Federation", approved by the decree of the Government of the Russian Federation of the $15^{\text {th }}$ of April, 2014 No. 323 "On the approval of the state programme of the Russian Federation "Providing affordable and comfortable housing and utilities of citizens of the Russian Federation", is to increase the availability of housing and the quality of housing for the population.

According to the current State programme of Moscow "Housing" (Government resolution of the $27^{\text {th }}$ of September, 2011 No. 454-PP "On approval of the State programme of Moscow "Housing") the provision of housing is estimated as $19.7 \mathrm{~m}^{2}$ per person. This figure is the lowest in comparison with the large megacities of Russia and large cities of the world. In the future it is expected to achieve the provision of housing $24.2 \mathrm{~m}^{2}$ per person.

The programme of renovation of the housing estate in Moscow (hereinafter - the Programme of renovation) was prepared and implemented in accordance with the Law of the Russian Federation from the $15^{\text {th }}$ of April, 1993 N 4802-I "On the status of the capital of the Russian Federation" (hereinafter - the Law of the Russian Federation "On the status of the capital of the Russian Federation"), the Law of city of Moscow from the $17^{\text {th }}$ of May, 2017 No. 14 "On additional guarantees of the housing and property rights of physical and legal persons during the implementation of the renovation of the housing estate in the city of Moscow" that was adopted in order to implement the aforesaid Law of the Russian Federation and the Moscow city law, normative legal acts of the city of Moscow on the basis of the 
results of voting and results of the General meetings of owners of premises in apartment houses, announced in the manner prescribed by resolution of the Government of Moscow from the $2^{\text {nd }}$ of May, 2017 No. 245-PP "On taking into account of opinion of the population on the project of renovation of the housing estate in the city of Moscow".

Thus, the development of economic policy of the country, dynamic changes in market relationships, competition in the construction market, the features of legal relations among the participants of investment-and-construction processes and the scale of construction in Moscow demand scientific calculations and rational choic of economic efficiency renovation of residential buildings.

\section{Literature review}

In accordance with the Decree of the Communist Party Central Committee and USSR Council of Ministers from 1954, "On the development of precast concrete structures and components for construction" 402 house-building plant for the production of reinforced concrete structures and 200 sites of the field type were built in the country. Thus, during industrialization of the country some major social-and-economic problems of that time, such as providing people with housing and jobs were solved. Millions of people were involved in the construction industry, working in various trades and professions: architects, engineers, economists, and financiers. Citizens built their housing by themselves, and the state financed the construction. The economic effect of this industrialization programme of housing construction throughout the country was tremendous.

Thus, there were different series of buildings of mass industrial construction, including II-07, B, 1-447, II-20,II-28, 1-303,1-335, II-32 (later 1-515/9ш) , II-35, K-7, 1 MG-300, 1605AM, 1-510, 1-511, 1-515. Series K-7, 1-510, 1-511, 1-515 had the largest spread in Moscow. 25.5 thousand $\mathrm{m}^{2}$ of total area of 5-storey residential houses, including 22.3 thousand $\mathrm{m}^{2}$ in the the most popular series K-7, 1-510, 1-511, 1-515 were built in Moscow only in 1956-1970. Table 1 demonstrates the volume of construction of 5-storey residential houses serial [1]

Table 1. Volume of construction of 5-storey residential houses serial (total area, thousand $\mathrm{m}^{2}$ ).

\begin{tabular}{|c|c|c|c|c|c|c|}
\hline \multirow{2}{*}{$\begin{array}{l}\text { Years of } \\
\text { construction }\end{array}$} & \multicolumn{6}{|c|}{ Series of a typical project } \\
\hline & II-32 & $\mathrm{K}-7$ & 1605-AM & $1-510$ & $\begin{array}{c}1-511 \\
\text { (brick) }\end{array}$ & $1-515$ \\
\hline 1951-1955 & & & & & 26 & \\
\hline 1956-1960 & 13 & 115 & 37 & 976 & 2343 & 341 \\
\hline 1961-1965 & 1138 & 2686 & 795 & 2941 & 4636 & 4247 \\
\hline 1966-1970 & 40 & 626 & 200 & 256 & 831 & 2045 \\
\hline 1971-1975 & & 8 & & 3 & 91 & 73 \\
\hline 1976-1980 & & & & & 2 & 3 \\
\hline 1981-1985 & & & & & & 3 \\
\hline TOTAL & 1191 & 3435 & 1032 & 4176 & 7929 & 6712 \\
\hline $\begin{array}{l}\text { Current } \\
\text { condition }\end{array}$ & $\begin{array}{c}85 \% \text { demolished, } \\
15 \% \text { remained in } \\
\text { the Western } \\
\text { administrative } \\
\text { district and East } \\
\text { administrative } \\
\text { district }\end{array}$ & $\begin{array}{l}98 \% \text { demolished } \\
2 \% \text { remained in the } \\
\text { North-Eastern } \\
\text { administrative } \\
\text { district }\end{array}$ & $\begin{array}{c}88 \% \text { demolished, } \\
12 \% \text { remained in } \\
\text { the } \\
\text { Western } \\
\text { administrative } \\
\text { district }\end{array}$ & $\begin{array}{l}\text { Included } \\
\text { in } \\
\text { the } \\
\text { program- } \\
\text { me of } \\
\text { renovation }\end{array}$ & $\begin{array}{l}\text { Included } \\
\text { in } \\
\text { the } \\
\text { program- } \\
\text { me of } \\
\text { renovatio } \\
n\end{array}$ & $\begin{array}{l}\text { Included } \\
\text { in } \\
\text { the } \\
\text { program- } \\
\text { me of } \\
\text { renovatio } \\
n\end{array}$ \\
\hline
\end{tabular}

The data in Table 1 prove, that the programme of reconstruction of five-storey buildings in Moscow supposes the demolishion of $85 \%$ of buildings of series II-32, $98 \%$ of buildings of series K-7 and $88 \%$ of the buildings of the series $1605-\mathrm{M}$. Buildings of such series as II- 
35 , 1 MG-300 today were completely demolished in 1999-2010, and 100 buildings of the series $1-447$ of the total built 300 buildings in this series remain nowadays.

The first stage of renovation of residential buildings in Moscow was the programme of comprehensive reconstruction of the residential areas of the first period of industrial housing. This included 1722 five-storey building of the series K-7, II-32, II-35, 1605-AM, 1 MG-300, which were built in the late $1950^{\text {th }}$ and early $1960^{\text {th }}$. According to the Moscow Government resolution of the $6^{\text {th }}$ July, 1999 No. 608 "On the problems of complex reconstruction of the areas of five-storey buildings of the first period of industrial housing construction until 2010" demolition of 1671 houses with the total area of 6.1 million $\mathrm{m}^{2}$ was carried out, which made up about $97 \%$ of the total programme of the complex reconstruction of the areas of fivestorey buildings of the first period of industrial housing.

The decree No. 608 "On the problems of complex reconstruction of the areas of fivestorey buildings of the first period of industrial housing construction until 2010" prohibited the demolition of the reconstructed 5-storey apartment houses of the series 515 (panel), 510 (rough), 511 (brick), 1-447 (brick), and equated. The decision to demolish the houses of these series individually was taken by the Moscow Government, based on some urban and economic studies. The lease rights and provision of land plots for commercial construction, not associated with the reconstruction programme, were also prohibited in the areas of the existing 5-storey building. Since 2000, the annual task of construction of the residential area for the purposes of resettlement of the demolished 5-storey residential buildings was planned in as not less than $1 \mathrm{mln} \mathrm{m}^{2}$ annually.

The demolition of five-storey houses of the "demolished" series is fully completed in the Central, Northern, Southern, South-Eastern, Eastern, Northwestern and Zelenograd administrative districts of Moscow. It is planned to have demolished 51 more building, with the area of 0.2 million $\mathrm{m}^{2}$ by 2020 . Then there is a programme of comprehensive reconstruction of the areas of five-storey buildings of the first period of industrial housing, carried out by the Government of Moscow since 1999 [2].

Financial mechanism of the complex reconstruction of 5-storey housing estate of the city of the first phase of the renovation had a mixed character. Funding was provided by public sources, by extra-budgetary funds of financial resources of administrative districts and by the investors ' funds.

According to the survey of bearing and non-bearing elements, engineering systems and equipment of apartment houses of the first period of industrial housing and similar characteristics of constructive elements of apartment houses of the State housing Inspectorate of Moscow city, it was revealed that the technical condition of the apartment houses, included in the Programme of renovation, is characterized by the decrease of the bearing capacity and operating characteristics of structures and in will not just reduce the next 10-15 years, but the consumer characteristics of housing, and will lead to emergency situation.

A significant portion of housing was built in the era of industrial housing, which began with the plan of reconstruction of Moscow in 1951-1960. As it was stated in the decree of the Government of Moscow from the $1^{\text {st }}$ of August, 2017 No. 497-PP, the renovation of the housing estate in Moscow is the set of measures, aimed at the upgrading of living environment and teh creation of favorable living conditions of citizens and public space in order to prevent the growth of emergency housing in Moscow, at the development of residential areas and their improvement. The programme was approved until 2032, in order to prevent an emergency situation in the city in the next 15 years.

If we trace the analogy of the term of the renovation of domestic and foreign experience, it is possible to meet concepts of reconstruction, alteration, conversion, modernization, rehabilitation and redevelopment of housing. These activities, along with new construction, is the form of reproduction of fixed funds and they also help to save financial, human and 
material resources by the means of the use of existing utilities, structural elements and engineering equipment of the buildings.

Each specialist gave his or her own definition of these terms.

Ovsyannikova T. Yu., refers to the reproduction of the housing fund as a continuous, renewable process of creating residential properties, distribution, exchange, consumption and renovation. The economic essence of its approach is in the fact that the production process of the dwelling is proposed to divide the actual construction of new facilities and partial repetition of production processes throughout its life cycle [3].

A clear description of the renovation of the dwelling house is given by Ovsyannikova $T$. $\mathrm{Yu}$. According to her opinion, "the renovation of houses" is the process of renewal of residential buildings, restoration of their consumer properties by replacing the physically and morally worn-out constructive structural and technical parts in order to maintain its consumer properties [3]. The main purpose of the renovation process is to bring existing housing estate into the line with modern requirements and standards of housing $[4,5,6,7]$, that will eventually lead to the domestic housing market with a high level of competitiveness of projects of housing construction and renovation [8].

Issues of economic effectiveness of investment-and-construction projects were studied by many Russian economists [9, 10, 11, 12, 13, 14,15,16].

As for foreign practice, many studies were conducted in this field. The article presents the research results of the reconstruction of buildings, aimed at solving the problem of stability of the entire upgrade process, including new categories, criteria and indicators. The sustainability framework was developed in cooperation with University of Palermo and Aarhus University for the auditing, development and assessment of the performance of building renovation, and for the decision-making support during the project's lifecycle" [17].

Continuous monitoring of the implementation of the renovation Programme will be carried out by the Department of economic policy and development of Moscow.

The main objective of the renovation Programme, declared in the act, is to prevent the mass appearance of dilapidated housing in Moscow and at the same time to adjust the imbalances in the development of the city, accumulated over the previous decades and to form the urban environment of new quality.

The order of execution of the measures for the implementation of the renovation Programme is consistent with the construction documentation, approved for these purposes, and technical condition for the apartment houses, included in the renovation Programme, as well as with the financial mechanisms and social-and-economic factors of the urban development of the capital.

Renovation of the housing estate will be based on the development of infrastructure, creation of additional conditions for the development of human potential, ecology, which ensures the comprehensive development territory in accordance with modern requirements to the urban environment.

The Programme of renovation also includes the following tasks:

- unloading of transport infrastructure;

- creation of the new urban environment, adapted for comfortable accommodation, rest and work;

- construction of the energy efficient apartment houses, leading to cutting of costs for their maintenance [18];

- improvement of the ecological situation of the housing estate;

- updating and modernization of engineering infrastructure;

- formation of modern architectural appearance of Moscow.

The development and implementation of economic models for the redevelopment and modernization of the typical panel buildings were engaged by German scientists in 1993 after the reunification of Germany. In the work by Hartmut Kalleja and Dieter Flaemig 
"Plattenbausanierung: Instandsetzung, staedtebauliche Entwicklung und Finanzierung" the economic policy of renovation of panel buildings in Eastern Germany was described and the analysis of all the houses, built from 1955 to 1990 was made [19]. It was offered demolish some buildings and to reconstruct the others. A special state programme was developed, which was successful in 1999.

Works by Moshood Olawale Fadeyi [20] were devoted to the improving the effectiveness of providing consumers with a sustainable cost of construction.

A significant factor of renovating buildings is its energy efficiency and the impact on the environment: "most of the apartment houses, built in the 20th century in Central and Eastern Europe do not meet modern requirements for energy efficiency", say scientists from Slovakia [21].

The matters of the positive impact of reconstruction of buildings on the ecosystem in the residential area were considered in works by scientists Ivan Andrića, André Pinaa, Paulo Ferrãoa, Bruno Lacarrièreb, Olivier Le: "finally, based on the emergency analysis of indicators, we can conclude that the use of building repair to enhance the overall building environmental performance, provides higher resource use efficiency in indigenous and reduces the pressure on the local ecosystem" [22].

The economic effect from the energy saving measures for renovation of buildings was noted in the work by Marcus Gustafsson, Chiara Dipasquale, Stefano Poppi, Alessandro Bellini, Sture Holmberg: "Compared to a purely functional renovation, the renovation packages studied resulted in up to $77 \%$ lower energy costs and $19 \%$ lower total annualized costs, $79 \%$ lower climate change impact, $89 \%$ lower non-renewable energy use, $66 \%$ lower particulate matter formation and $76 \%$ lower freshwater eutrophication impact over a period of 30 years. The lowest total costs and environmental impact, in all of the climates studied, were seen for the buildings with the lowest heating demand". [23]

The economic need of renovation apartment panel houses exists in Italy. According to Graziano Salvalai, Marta Maria Sesana, Giuliana Iannaccone:«More than $60 \%$ of the existing building stock in Lombardy region has been built before the $70 \mathrm{~s}$ and it is among the main responsible causes of final energy absorption and corresponding $\mathrm{CO} 2$ emissions with a mean primary energy index for heating of about $202.0 \mathrm{kWh} / \mathrm{m} 2 \mathrm{y}$. The promotion of renovation measures for such buildings, also through innovative solutions, is becoming increasingly important for both containing the greenhouse gas emissions and supporting the growth of the construction sector» [24].

Experts from Technical Research Centre of Finland also studied the need for renovation of panel residential buildings: «Most of the apartment buildings in the Soviet Union were constructed between 1960 and 1985, and as a result the urban housing stock today consists mainly of a few standard building types. Energy efficiency of buildings is typically poor. A typical residential district was selected for the analyses. The energy consumption of a typical Russian building was estimated by calculating heating of living spaces, heating of domestic hot water, and the consumption of electricity. Energy and emission analyses of renovation scenarios of a Moscow residential district... At the district level, four different energy renovation scenarios, called Current, Basic, Improved and Advanced, were analyzed in terms of energy demand and emissions. Considerable energy savings could be achieved, up to $34 \%$ of the electricity demand and up to $72 \%$ of the heating demand, using different district modernization scenarios» [25].

The need of renovation of residential buildings was also proved by the work by Satu Paiho, Rinat Abdurafikov, Ha Hoang, Johanna Kuusisto : «The Russian apartment building estate is old and its energy efficiency is poor. Due to the technical structure of the district heating used in Russia, energy renovations of single buildings seldom lead to reduced energy production. Energy production demands are reduced only if the residential districts and their various utilities and networks are renovated holistically» [26]. 
Economic and environmental problems in the upgrade process, are also described in the work by other scientists [27].

\section{Materials and methods}

It should be noted that energy consumption of residential development will inevitably increase during the renovation process, and, consequently, the cost of housing as a market commodity will increase. Currently, there will be a tendency to the sharp decrease in the supply and the increase in demand for apartments in the five-story building, included in the renovation program in Moscow. Many families refused to sell apartments, as in the long term plan to purchase a comfortable home at the expense of the city budget.

In order to ensure the comfort of houses, built under the renovation Programme, approaches to the design of residential buildings are being introduced.

Evaluation of the effectiveness of the state programme of renovation will be done in several ways. The first way is the assessment of social-and-economic efficiency to justify, that the social-and-economic, urban planning and investment decisions are made for the benefit of the city. Definition of economic efficiency will be calculated with the use of indicators of improved consumer quality of apartments, houses, districts.

The second ways is the estimation of budget effectiveness, comparing the cost and incomes of the budget during the implementation of the investment project. According to the Budget Code of the Russian Federation (Item 34) the "participants of the budget process within the established budget authority is due to proceed from the need to achieve the desired results with the least amount or best results using a specific budget amount".

The third way is to assess the efficiency of State programmes by the method, approved by the decision of the Government of Moscow from 08.04.2015 No. 189-PP. The efficiency can be calculated with the use of the final results of the State programme, taking into account the weight coefficients, with the weights determined by the experts. The implementation of the State programme will be considered as excellent, if the efficiency is more than $100 \%$; as good if the efficiency is $95 \ldots 100 \%$; as satisfactory, if the efficiency is $75 \ldots 95 \%$; and as unsatisfactory, if the efficiency is less than $75 \%$.

\section{Results}

Renovation of residential buildings requires significant investment, and therefore, there arises the problem of recovery of costs when making decision on the necessity and possibility of implementation of the planned state programme. One should analyze the market and to predict it on the basis of calculations of costs and revenues. The most important parameters are the duration of the renovation are the payback period of the funds, the amount of profit and profitability index. The owner of the property determines by the amount of funds, required to perform renovations and to provide the specific set of consumer qualities. When calculating the economic efficiency of the implementation of the renovation, one should use data on the amount of required capital investment, the rate of bank loans, the expected period of cost recovery, and also one should use the apparatus of discounting.

The author proposes to calculate the amount of funds on renovation of residential buildings according to the following formula (1):

$$
K_{\sigma}=\sum_{t_{0}}^{T} \sum_{r_{1}}^{R} m_{r} K_{r} \cdot\left(1+\frac{\beta r}{100}\right)^{t_{r}}
$$

where: $K_{\sigma}$ - the volume of investments, taking into account credit rates at the moment of completion of renovation;

$t=t_{0}, T-$ period (months) from the start to completion of renovation; 
$r=r_{1}, R$ - operations on attraction of funds to complete the renovation (determined by the schedule of funding);

$K_{r}$ - the funds raised by the operation "r";

$\beta_{r}$ - the rate of interest on loan in cash "r";

$m_{r}$ - the share of investment funds "r" months;

$t_{r}-$ time (months) from start of renovation until the end. loan.

The formula takes into account the time factor, taking into account the interest rate on the

We offer to use the following formula for the definition of the moment of covering of expenses by the investor and the possible monthly size of the rent after renovation for inhabited and non-residential premises: (2):

$$
A=\frac{\sum_{1}^{N} K_{\sigma} \cdot\left(\frac{1}{N}+(1-n / N)\right) \cdot \beta}{N \cdot S},
$$

where: A - monthly rent per $1 \mathrm{~m}^{2}$ of floor total area;

$\mathrm{N}=1, \mathrm{~N}$ - periods (months) from completion until repayment of the loan (loans);

$\mathrm{S}-$ the total area of the premises, rent, rental;

$\beta$ - the rate of interest (lending rate).

Formula (2) leads to the calculation of the specified time before anticipated expenses in the given period of time. If the rent would be unrealistic for the market conditions, one should take a longer period before the time of cost recovery. The reality of this period is one of the indicators, along with the amount of rent, determining the efficiency of renovation.

As the result of renovation, the monthly rent will increase as (3):

$$
\Delta A=A_{r}-A_{0},
$$

where $A_{r}, A_{0}-$ rent before and after renovation of the facility.

This technique demonstrates a flexible mechanism of real estate management at its further use, particularly in case of rent

\section{Discussion}

The proposed methodology evaluates the performance of organizational measures of the state programme as a percentage and is the only part of the assessment of the overall social-andeconomic efficiency.

The principles of economic efficiency will consist of the following indicators:

- formation of structure of cash flows on the predicted volumes of data, structure of schedules of expenses and income at the predicted prices;

- the comparative analysis of initial investments into the project and actually realized at reconstruction;

- the analysis of discounting of investments and cash flows, taking into account a refunding rate of the Central Bank of Russia;

- definition of cash flows from the offered investment offers and on the basis of their calculation of an integrated indicator of efficiency of the project of renovation of housing.

It should be noted, that the time factor will be the major, and sometimes and a decisive factor when calculating economic efficiency, therefore the reduction of duration of construction works has to be the purpose.

\section{Conclusions}


The social-and-economic efficiency of reconstruction of residential buildings is obvious because:

- there is no need to buy or lease any new land plots for construction;

- the increase in housing due to repair is 1.5 times cheaper, than in case of new construction, because the existing engineering infrastructure is used;

- economy of heat and hot water is about $35-50 \%$ and the economy of cold water is about $40-50 \%$ and, therefore, there is the decrease in load of removal of sewage;

- repair increases the quality of architecture of the housing estate;

- repair creates comfortable and safe life of citizens, including updating of the lift equipment;

- repair achieves the objectives of step availability of social, cultural and household purpose due to placement such organizations for residents of the area on the first floors of houses.

The return on investment in the reconstruction from the city budget will be carried out during the long period due to receipts from:

- the rent, including utility and operational payments and also operational payments have to be included in the cost of future planned routine maintenance and overhaul repairs of residential buildings;

- delivery of premises for rent in again built housing;

- operation of garages and parking in residential areas;

- the current payments on the installed modern counters consumed heat, water, gas;

- insurance premiums under contracts of insurance of apartments and the general property;

- property taxes of modern apartments at their cadastral cost, and transition to the market value of assessment is possible further;

- tax and other mandatory fees on operations with the real estate after repair. The sum will vary depending on taxation methods.

When calculating economic efficiency of reconstruction it is necessary to consider future economy of expenses on:

- refusal of capital repairs of houses of the not taken down series included in the townplanning decision in the program of reconstruction and demolition;

- refusal of reconstruction or capital repairs of the social facilities which are subject to reconstruction;

- cancellation of scheduled repairs and modernization of infrastructure, engineering networks and communications, repair of a paving;

- introduction of the innovative energy saving and heatpreserving designs, technologies, developments.

The offered method of assessment of economic efficiency of reconstruction will allow to make economically reasonable decision at various stages of city-planning activity: preliminary preparation, planning of the territory, development and the approval of the design-and-estimate documentation.

\section{References}

1. The research report of GUP MNIITEP on the topic: "lessons learned from the reconstruction and operation of industrial 5-9-12 storey houses of typical series" (Moscow, 2002)

2. The resolution of the Moscow Government dated 1 August 2017 N 497-PP "About the Program of renovation of the housing stock in the city of Moscow" 
3. T.Yu. Ovsyannikova, Investment in housing (GOV't. architect.-builds. Univ., Tomsk 2005)

4. O.M. Goryachev, A.V. Krotov, Concrete and reinforced concrete - glance at future : scientific papers of the III all-Russian (II International) conference on concrete and reinforced concrete: in 7 volumes, 19-25 (2014)

5. P.G. Grabovy, Urban Governance and modernization of housing and utilities infrastructure (Illuminator, 2013)

6. A.A. Afanasev, V.F. Kasyanov, I.G. Lukmanova, D.N. Silka, International Journal of Economics and Financial, 158-160 (2015)

7. M.A. Numello, Perspectives of development of science and education: collection of scientific works on materials of the International scientific-practical conference : in 8 parts, 102-105 (2013)

8. E.V. Neznikova, PhD Thesis (Moscow, 2017)

9. P.G. Grabovy, A.K. Orlov, Procedia Engineering 153, 195-202 (2016)

10. I. Lukmanova, N. Yaskova, H. Reserves, Procedia Engineering 165, 1293-1299 (2016)

11. V. Kankhva, D. Silka, Procedia Engineering 165, 1337-1342 (2016)

12. D.N. Silka, I.G. Lukmanova, A.A. Afanasev, M.A. Kasyanov, International Journal of Economics and Financial Issues 5(3s), 121-124 (2015)

13. A.A. Kokoshin, B.I. Bartenev, Studies on Russian Economic Development 6, 6-18 (2016)

14. M.I. Kamenetskii, N.Y. Yaskova, Studies on Russian Economic Development 2(26), 124-131 (2016)

15. M.I. Kamenetsky, Forecasting problems 3, 76-91 (2013)

16. L.V. Prykina, A.K. Orlov, Procedia Engineering 165, 1388-1394 (2016)

17. A. Kamari, R. Corrao, P. H. Kirkegaard, International Journal of Sustainable Built Environment, 1-21 (2017) doi.org/10.1016/j.ijsbe.2017.05.001

18. E. Chibisova, T. Meshcheryakova, Krasnoyarye Science, 6 (2-2), 146-148 (2017)

19. H. Kalleja, D. Flaemig, Springer-Verlag Berlin Heidelberg, 121-155 (1999)

20. M.O. Fadeyi, International Journal of Sustainable Built Environment (2017) https://doi.org/10.1016/j.ijsbe.2017.08.003

21. V. Földváry, G. Bekö, S. Langer, K. Arrhenius, D. Petráš, Original research article Building and Environment 122, 363-372 (2017)

22. I. Andrića, A. Pinaa, P. Ferrãoa, B. Lacarrièreb, O. Le, Journal of Cleaner Production 162, 776-790 (2017)

23. M. Gustafsson, C. Dipasquale, S. Poppi, A. Bellini, S. Holmberg, Original research article Energy and Buildings 148, 155-165 (2017)

24. G. Salvalai, M.M. Sesana, G. Iannaccone, Original research article Energy and Buildings 148, 23-36 (2017)

25. S. Paiho, H. Hoang, Å. Hedman, R. Abdurafikov, M. Sepponen, M. Meinander, Energy and Buildings 76, 402-413 (2014)

26. S. Paiho, R.Abdurafikov, H. Hoang, J. Kuusisto, Sustainable Cities and Society 14, 3142 (2015)

27. W. Ott, R. Bolliger, Energy Procedia 78, 2340-2345 (2015) 